ACTA MYCOLOGICA

Vol. 45 (1): 91-96

2010
Dedicated to Professor Barbara Gumińska

on the occasion of her eighty-fifth birthday

\title{
Interesting collections of phytopathogenic fungi
}

\author{
AGATA WOLCZAŃSKA \\ Department of Botany and Mycology, M. Curie-Skłodowska University \\ Akademicka 19, PL-20-033 Lublin, agata.wolczanska@poczta.umcs.lublin.pl
}

Wołczańska A.: Interesting collections of phytopathogenic fungi. Acta Mycol. 45 (1): 91-96, 2010.

Ascochyta chaerophylli Bres. and Ramularia vallisumbrosae Cavara are reported as new in Poland. Passalora bupleuri (Pass.) U. Braun on Anthriscus sylvestris (L.) Hoffm. is a new fungus/host combination and ten other rare species are recorded from new localities in the country.

Key words: Ascomycota, anamorphic fungi, new records, distribution

\section{INTRODUCTION}

Recently issued "A preliminary checklist of micromycetes in Poland" (Mułenko et al. 2008) contains information about 5969 fungal species reported from this country. It is a big amount, but on the map of Poland there are still regions which can be called "white spots" - with no information about phytopathogenic fungi, especially about anamorphic fungi. The present paper provides new data about 13 species collected recently in Poland. Two of them are new for Poland, one is found on a new host plant and others were noted only on a few localities till now. They were collected in various regions of Poland, but most of the stands are situated in the south part.

\section{MATERIALS AND METHODS}

The collected specimens were air dried and examined by means of standard light microscopy. Slide preparations were stained with cotton blue in lactic acid and warmed. The publications of Braun (1998), Crous and Braun (2003), Mel'nik (2000), Sałata $(1974,1979,2002)$ and Teterevnikova-Babajan (1987) were used for identification. The species new for Poland are briefly described, illustrated and discussed. The remaining 
species are enumerated with full details of new collection(s) and information on their previous findings in Poland. The nomenclature of host plants follow Mirek et al. (2002) and the names of physico-geographical regions of Poland follow Kondracki (1998). All the collected specimens are deposited in the herbarium of the Botany and Mycology Department of Maria Curie-Skłodowska University in Lublin (LBL) and W. Szafer Institute of Botany of Polish Academy of Sciences in Kraków (KRAM).

\section{RESULTS AND DISCUSSION \\ SPECIES NEWLY FOUND IN POLAND}

\section{Ascochyta chaerophylli Bres.}

Leaf spots small, circular, 4-6 mm in diameter, yellow-brownish with darker margin; pycnidia inconspicuous, immersed in the leaf tissue, with brown-yellowish wall, $100-140 \mu \mathrm{m}$ in diameter; conidia cylindrical, rounded at both ends, 2-celled, slightly constricted at the septum, 12-14 × 3.5-4.0 $\mu \mathrm{m}($ Fig. 1F).

Specimen examined. On Chaerophyllum hirsutum L.Western Carpathians, Beskid Niski Mts: Iwonicz Zdrój health resort, slope of Glorieta Mt., roadside, 16 Sept. 1993, leg. $A$. Wotczańska, LBL M-10062.

Remarks. This species is new to Poland. It was previously reported on Chaerophyllum spp. in the former Czechoslovakia, Germany, Lithuania and United Kingdom (Mel'nik 2000). In addition, Ascochyta chaerophylli has been reported on Falcaria vulgaris Bernh. and Sanicula europaea L. in Moravia in the Czech Republic (Sałata 2002).

\section{Ramularia vallisumbrosae Cavara}

Leaf spots elliptical, oblong, $10-25 \times 4-8 \mathrm{~mm}$, at first yellow-brownish, brown, green-brownish, later with light center; leaf spots surrounded by a green halo, well visible on fading leaves. Caespituli amphigenous (Figs 1A, B). Conidiophores emerged from well developed stroma-like hyphal aggregations, 10-180 $\times 2.5-3 \mu \mathrm{m}$ (Fig. 1 C). Conidia catenate, 2-4-celled, ellipsoid-ovoid to cylindrical, 14-44 $\times 2-4$ $\mu \mathrm{m}$ (Fig. 1 D).

Specimens examined. On Leucojum vernum L. Eastern Carpathians, Bieszczady Mts: vicinity of Muczne village, Alnetum incanae, 1 May 2007, leg. M. Piatek, KRAM F-46634; Bereżki village, 4 May 2007, leg. M. Piątek, KRAM F-46635.

Remarks. In his monograph, Braun (1998) mentioned this species from Poland. In the available literature as well as in Polish herbaria I did not find any reports or voucher specimens of Ramularia vallisumbrosae from the territory of the country. It cannot be excluded that Braun (1998) studied specimen(s) from German or other herbaria. Anyway, this is the first clearly documented report of Ramularia vallisumbrosae from Poland.

General distribution of this species includes Europe and North America, but on Leucojum it was noted only in the Ukraine (Braun 1998) and Austria (Farr, Rossman 2009). 


\section{NEW LOCALITIES OF SPECIES ALREADY KNOWN FROM POLAND}

\section{Cercospora zebrina Pass.}

Specimen examined. On Trifolium repens L.Western Carpathians, Pogórze Bukowskie foothills: Rymanów town, meadow, 11 June 1994, leg. A. Wotczańska, LBL M-10053.

Remarks. This species has been hitherto reported from Poland only few times. On Trifolium repens it was known from Pojezierze Łęczyńsko-Włodawskie lakeland (Mułenko 1988) and Rogoźnica village (Danilkiewicz 1987). Other hosts of this species are: Trifolium dubium Sibth. and Trifolium sp. (Świderska-Burek 2008a).

Cladosporium variabile (Cooke) G. A. de Vries

SPecimen examined. On Spinacia oleracea L. Wyżyna Lubelska upland: Lublin city, 11 May 2004, leg. M. Chmiel, LBL M-10055.

Remarks. Cladosporium variabile has been hitherto reported in Poland only from Lubartów town (Moesz 1920, 1926), but it is possibly common in regions where spinach is cultivated because the general distribution of this species is very broad. It was reported from many countries in Asia, Europe and North America (USA) (Dugan et al. 2004).

\section{Passalora bupleuri (Pass.) U. Braun}

Specimen examined. On Anthriscus sylvestris (L.) Hoffm. Western Carpathians, Pogórze Bukowskie foothills: Rymanów town, meadow, 11 June 1994, leg. A. Wołczańska, LBL M-10056.

Remarks. Anthriscus sylvestris is a new host for Passalora bupleuri in Poland; previously it was reported in this country on Anthriscus nitida (Wahlenb.) Hazsl., Chaerophyllum bulbosum L., Ch. hirsutum L., Ch. temulum L. and Coriandrum sativum L. (Świderska-Burek 2008b).

\section{Protomyces kreuthensis Krieg.}

Specimens examined. On Aposeris foetida (L.) Less. Western Carpathians, Pogórze Bukowskie foothills: Zmysłówka village, Dentario glandulosae-Fagetum, 2 June 1991, leg. A. Wotczańska, LBL M-8639; EASTern CARPATHIAns, Góry Sanocko-Turczańskie Mts: Turnica Reserve, Dentario glandulosae-Fagetum, 5 May 2007, leg. M. Piatek, KRAM F-46529.

Remarks. This species has been previously known only from one locality in the Bieszczady Mts (Sałata 1979).

Ramularia crassiuscula (Unger) U. Braun

Specimen examined. On Delphinium oxysepalum Borbás \& Pax. Western Carpathians, Tatra Mts: Kobylarzowy Żleb gully in the Czerwone Wierchy massif, 7 Aug. 2004, leg. J. Piątek \& M. Piatek, KRAM F-46533.

RemARKs. Ramularia crassiuscula has been recently reported from the Tatra National Park on Delphinium oxysepalum growing on Ciemniak Mt. (Mułenko, Wołczańska 2004). The present locality is also in the Czerwone Wierchy massif in the Tatra National Park, but within the distance about $1 \mathrm{~km}$ from the previously published station. 


\section{Ramularia libanotidis Bubák}

Specimen examined. On Falcaria vulgaris Bernh. Wyżyna MaŁopolska upland: Zwierzyniec village, $\mathrm{N}$ of Busko Zdrój town, xerothermic grassland, 10 July 2004, leg. J. Piątek \& M. Piątek, KRAM F-46535.

REMARKs. This species has been so far reported from Poland only twice. Schroeter (1908) found it on Falcaria vulgaris in Dzierżysław town near Głubczyce town, and Wołczańska (2005) detected the species on Pimpinella saxifraga L. in Lipowica village near Dukla town.

\section{Septoria hydrocotyles Desm.}

Specimen examined. On Hydrocotyle vulgaris L. Pobrzeża PoŁudniowobaŁtyckie littoRALS: near Jastarnia town, meadow, 7 Sept. 1999, leg. A. Wotczańska, LBL M-10052.

Remarks. Septoria hydrocotyles has been rarely reported from Poland; it was known from surroundings of Konotop town near Zielona Góra town (Hellwig 1899), Jezioro Czarcie lake near Goleniów town (Kućmierz 1974), Anieliny village (Michalski 1982), Pojezierze Łęczyńsko-Włodawskie lakeland (Mułenko 1988), and from Szewce village near Janów Lubelski town (Romaszewska-Sałata et al. 1997, Romaszewska-Sałata, Wołczańska 1997).

\section{Septoria melampyri Strasser}

Specimens examined. On Melampyrum pratense L. Pobrzeża Poludniowobattyckie LiTTORAls: between Chałupy village and Kuźnica station, pine forest, 10 Sept. 1999, leg. A. Wołczańska, LBL M-10058; between Kuźnica station and Jastarnia town, pine forest, 11 Sept. 1999, leg. A. Wotczańska, LBL M-10059.

Remarks. In Poland, Septoria melampyri has been hitherto known only from Białowieża National Park (Mułenko 1996; Faliński, Mułenko 1997).

\section{Septoria polemonii Thüm.}

Specimen examined. On Polemonium caeruleum L. Pojezierza PoludniowobaŁtyckie LitTORAls: Torfowisko Kopaniarze peat-bog, E of Brodnica town, eutrophic mire, 10 Sept. 2004, leg. J. Piatek \& M. Piatek, KRAM F-46537.

Remarks. The only previous report of Septoria polemonii from Poland derives from one hundred years ago: Diedicke (1915) found this species in Kostrzyn town in October 1904.

\section{Septoria villarsiae Desm.}

Specimen eXamined. On Nymphoides peltata (S. G. Gmel.) Kuntze: Brama KrakowsKa GATE: Kraków city, Botanical Garden, 23 July 2004, leg. M. Piątek, KRAM F-46536.

Remarks. This is the second record of Septoria villarsiae in Poland. It was previously reported by Moesz (1926) from Zagożdżon reserve and this locality is now probably situated in the Kozienicki Landscape Park.

\section{Taphrina rhizophora Johanson}

Specimen examined. On Populus alba L. Brama Krakowska gate: Kraków-Nowa Huta city, near Łąki Nowohuckie meadow, 24 Apr. 2007, leg. M. Piątek, KRAM F-46638 (Fig. 1E). 

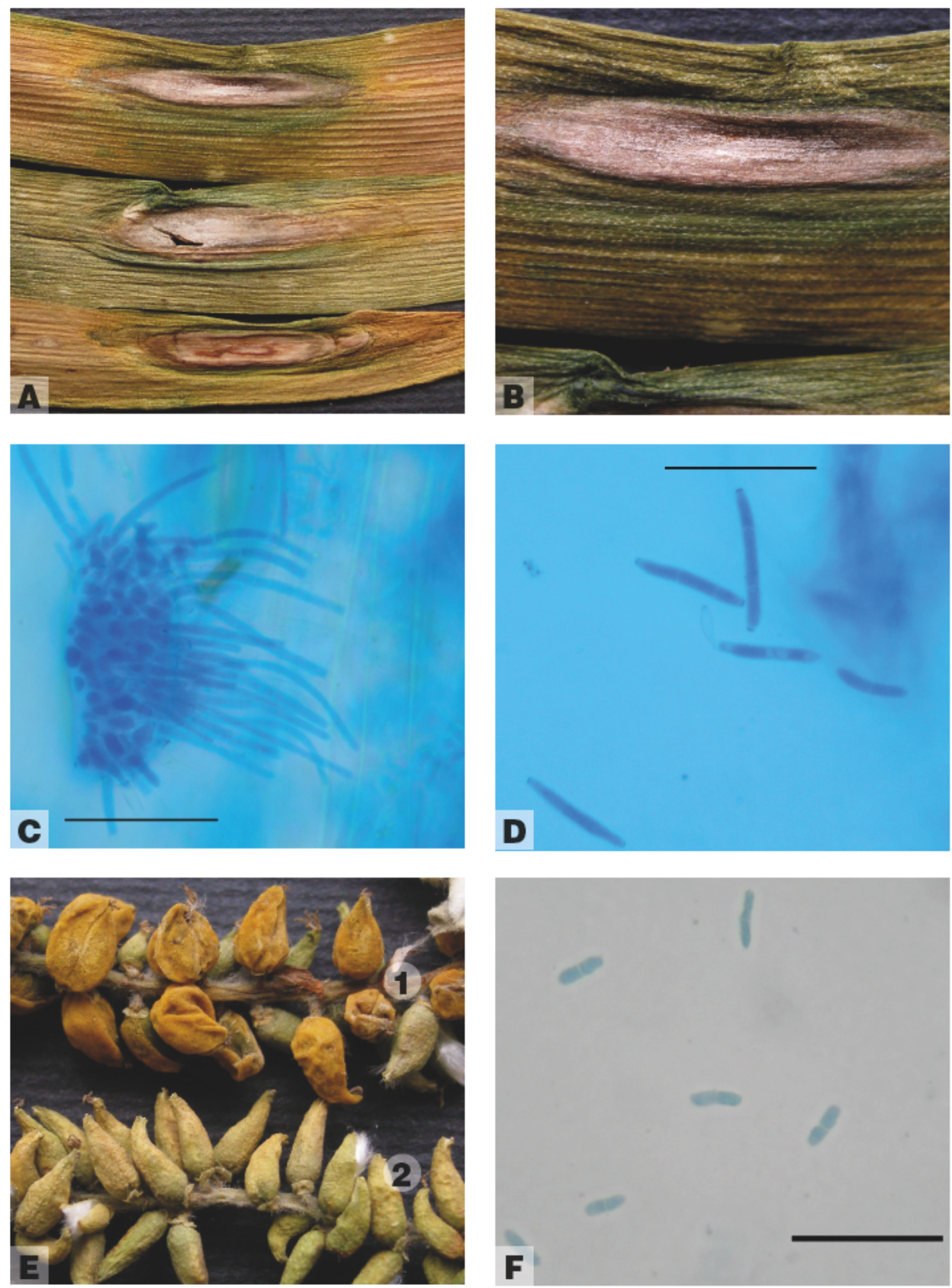

Fig. 1. A, B, C, D - Ramularia vallisumbrosae on Leucojum vernum; E - Taphrina rhizophora on Populus alba (1 - specimen infected, 2 - specimen uninfected); F - Ascochyta chaerophylli on Chaerophyllum hirsutum. Scale bars $=20 \mu \mathrm{m}$. 
REMARKs. The species has been reported from only 5 localities in Poland so far: Murowana Goślina town, Ludwikowo village, Usarzewo village, Bartniki village, Puławy town (Sałata 1974).

Acknowledgements. I am very grateful to Maria Chmiel, Marcin Piątek, and Jolanta Piątek, for permission to publish their collections. The paper was partially supported by grant from the Ministry of Science and Higher Education (MNiSW) No N/N304/172436.

\section{REFERENCES}

Braun U. 1998. A monograph of Cercosporella, Ramularia and allied genera (phytopathogenic Hyphomycetes). Vol. 2. IHW Verlag, Eching.

Crous P. W., Braun U. 2003. Mycosphaerella and its anamorphs: 1. Names published in Cercospora and Passalora. CBS Biodiversity Series 1. Centraalbureau voor Schimmelcultures, Utrecht.

Danilkiewicz M. 1987 Parasitic fungi occurring on meadows and pastures in the Krzna river valley. Zesz. Probl. Post. Nauk Roln. 307: 91-104 (in Polish with English and Russian summary).

Diedicke H. 1915. Kryptogamenflora der Mark Branderburg. Bd. IX. Pilze VII. Sphaeropsideae, Melanconieae. Verlag von Gebrüder Borntraeger, Leipzig.

Dugan F. M., Schubert K., Braun U. 2004. Check-list of Cladosporium names. Schlechtendalia 11: $1-103$.

Faliński B., Mułenko W. (eds). 1997. Cryptogamous plants in the forest communities of Białowieża National Park. Ecological atlas (project CRYPTO 4). Phytocoenosis 9 (N.S.), Supplementum Cartographiae Geobotanicae 7: 1-522.

Farr D.F., Rossman A.Y. 2009. Fungal Databases, Systematic Mycology and Microbiology Laboratory, ARS, USDA. Retrieved November 29, 2009, from http://nt.ars-grin.gov/fungaldatabases/.

Hellwig T. 1899. Florenbild der Umgegend von Kontopp im Kreise Grünberg in Schlesien. Allgemeine Botanische Zeitschrift 5: 140-142; 157-160.

Kondracki J. 1998. Geografia regionalna Polski. Państwowe Wydawnictwo Naukowe, Warszawa.

Kućmierz J. 1974. A contribution to the knowledge of fungal parasitic flora of Western Pomerania (NorthWestern Poland). Fragm. Flor. Geobot. 20: 271-275.

Mel'nik V. A. 2000. Key to the fungi of the genus Ascochyta Lib. Mitteilungen aus Biologischen Bundesanstalt für Land- und Forstwortschaft 379: 1-192.

Michalski A. 1982. Parasitic fungi of Noteć meadows and neighbouring areas adjacent on the stretch Nakło - Ujście. Acta Mycol. 18: 175-202.

Mirek Z., Piękoś-Mirkowa H., Zając A., Zając M. 2002. Flowering plants and pteridophytes of Poland. A checklist. Biodiversity of Poland 1: 1-442. W. Szafer Institute of Botany, Polish Academy of Sciences, Kraków.

Moesz G. 1920. Beiträge zur Kenntnis der Pilzflora von Polen. I. Mitteilung. Botanikai Közlemények 18: 22-28, (6)-(13).

Moesz G. 1926. Additamenta ad cognitionem fungorum Poloniae. II. Magyar Botanikai Lapok 1/12: 25-39.

Mułenko W. 1988. The microscopic pathogenic fungi of the Łęczna-Włodawa Lake District. II. The list of species. Acta Mycol. 24: 125-171.

Mułenko W. 1996. Parasitic microfungi and their hosts collected on the study area. Plant pathogenic fungi. (In:) J. B. Faliński, W. Mułenko (eds). Cryptogamous plants in the forest communities of Białowieża National Park (Project CRYPTO). Phytocoenosis 8 (N. S.), Archivum Geobotanicum 6: 55-65.

Mułenko W., Majewski T., Ruszkiewicz-Michalska M. (eds). 2008. A preliminary checklist of micromycetes in Poland. Biodiversity of Poland 9: 1-752. W. Szafer Institute of Botany, Polish Academy of Sciences, Kraków.

Mułenko W., Wołczańska A. 2004. New collections of Ramularia species (Hyphomycetes) in Poland. Acta Mycol. 39 (1): 13-17.

Romaszewska-Sałata J., Sałata B., Wołczańska A. 1997. New and rare species of Sphaeropsidales in the Polish flora. II. Acta Mycol. 32 (2): 293-301.

Romaszewska-Sałata J., Wołczańska A. 1997. Mikroskopowe grzyby fitopatogeniczne Parku Krajobrazowego „Lasy Janowskie”. (In:) S. Radwan, B. Sałata, M. Harasimiuk (eds). Środowisko przyrodni- 
cze Parku Krajobrazowego „Lasy Janowskie”. Wydawnictwo UMCS, AR Lublin, Park Krajobrazowy „Lasy Janowskie”, Lublin: 57-63.

Sałata B. 1974. Flora Polska. Grzyby (Mycota) 6: Ascomycetes, Taphrinales. PWN, Warszawa-Kraków.

Sałata B. 1979. Flora Polska. Grzyby (Mycota) 12: Ascomycetes, Protomycetales. PWN, WarszawaKraków.

Sałata B. 2002. Polskie gatunki grzybów mitosporowych z rodzaju Ascochyta. Wydawnictwo UMCS, Lublin.

Schroeter J. 1908 (1897). Die Pilze Schlesien. (In:) F. Cohn (ed.). Kryptogamen-Flora von Schlesien 3(2). J. U. Kern's Verlag, Breslau.

Świderska-Burek U. 2008a. Cercospora, Cercosporella, Cercosporidium. (In:) W. Mułenko, T. Majewski, M. Ruszkiewicz-Michalska (eds). A preliminary checklist of micromycetes in Poland. Biodiversity of Poland 9: 353-358. W. Szafer Institute of Botany, Polish Academy of Sciences, Kraków.

Świderska-Burek U. 2008b. Passalora. (In:) W. Mułenko, T. Majewski, M. Ruszkiewicz-Michalska (eds). A preliminary checklist of micromycetes in Poland. Biodiversity of Poland 9: 436-440. W. Szafer Institute of Botany, Polish Academy of Sciences, Kraków.

Teterevnikova-Babajan D. N. 1987. Griby roda Septoria in SSSR. Izdatel'stvo Akademii Nauk Armjanskoj SSR, Erewan (in Russian).

Wołczańska A. 2005. The Ramularia species in Poland. Monogr. Bot. 95: 1-154.

\section{Nowe informacje o grzybach fitopatogenicznych w Polsce}

\section{Streszczenie}

Praca zawiera dane na temat występowania 13 gatunków grzybów workowych (w stadium anamorfy i teleomorfy). Dwa z nich (Ascochyta chaerophylli, Ramularia vallisumbrosae) są nowe dla Polski, Passalora bupleuri została zebrana na nowym żywicielu (Anthriscus sylvestris), a pozostałe znane są z nielicznych stanowisk. 